\title{
EARTHQUAKE DAMAGE AT EDGECUMBE AND KAWARAU ELECTRICORP SUBSTATIONS IN THE BAY OF PLENTY EARTHQUAKE ON 2 MARCH 1987
}

\author{
A. L. Rutledge*
}

SUMMARY

\begin{abstract}
This paper describes the major damage to Edgecumbe and Kawerau substations in the Bay of Plenty earthquake on 2 March 1987. Questions such as why the equipment failed and what actions should be taken to strengthen the equipment are addressed.
\end{abstract}

Ed1tor's Note : This paper was first published in the Transactions of the 58 th Annual Conference of the Electric Supply Authority Engineers' Institute of New Zealand Inc., vol. 57, 1987 and is reprinted with their permission.

\section{INTRODUCTION}

\begin{abstract}
The Electricity Corporation (formerly Electricity Division) has specified relatively high seismic design factors for new electrical equipment since 1968 and has also upgraded many of the more important older installations, especially in the HVDC link, where a better understanding of earthquake effects has indicated weaknesses.
\end{abstract}

The substation damage sustained in the Bay of Plenty earthquake was confined mainly to equipment installed before 1968 and was a timely reminder that all older substations should be checked for resistance to earthquakes and upgraded when necessary.

In many instances upgrading can be easily carried out and the relatively low cost if the modifications is not difficult to justify. At Edgecumbe and Kawerau a large proponion of the total cost of the damage was due to inadequate holding down of transformers which had originally been designed to only $0.15 \mathrm{~g}$. If the transformer fixings had been upgraded to the present requirement of $0.75 \mathrm{~g}$ it is likely that most ofthe transformer damage would have been avoided, at a comparatively small cost.

\section{THE EARTHQUAKE}

The main shock on 2 March measured 6.3 on the Richter Scale with an epicentre near the town of Edgecumbe and an epicentral depth of about $10 \mathrm{~km}$ [1]. Four aftershocks with magnitudes in excess of 5.0 occurred later in the day.

The main shock produced a complex surface scarp about $6 \mathrm{~km}$ long striking $S W$ from near Edgecumbe. About $\mathrm{Im}$ of extension occurred across the scarp with the area to the northwest being downthrown by about $1.5 \mathrm{~m}$.

* Formerly Earthquake Engineer,

Electricity Corporation, Wellington
Strong motion accelerographs recorded peak ground accelerations of up to $0.33 \mathrm{~g}$ at the base of the Mdatahina dam, $15 \mathrm{~km}$ from the epicentre. Processing of the strong motion data by the DSIR Physics and Engineering Laboratory has produced a response spectrum surprisingly like the 1940 El Centro N-S spectrum. Response spectra are given in Figure 1.

The earthquake was therefore quite representative of the Electricorp design earthquake for which the El Centro $1940 \mathrm{~N}-\mathrm{S}$ is one of the 8 component spectrum.

\section{DESCRIPTION OF DAMAGE}

Edgecumbe and Kawarau substations were extensively damaged [2]. Detailed inspections revealed that much of the damage was avoidable if better workmanship and current design practices had been used for the holding down of control panels and transformers.

\section{Control Panels}

The control and relay room at Edgecumbe had three parallel rows of $2140 \mathrm{~mm}$ high $\times 450 \mathrm{~mm}$ deep $x 600 \mathrm{~mm}$ wide control panels down on a wooden plinth (NZ Oregon) by $8 \mathrm{~mm}$ coach screws. Although the panels were tied longitudinally and laterally with $25 \mathrm{~mm} \mathrm{x}$ $25 \mathrm{~mm} \times 6 \mathrm{~mm}$ angle iron they were not braced to the walls. All three rows pulled the coach screws from the wood and fell forward like dominoes until the front row struck the operators cubicle.

Coach screws offer little resistance to overturning and this method of securing panels is no longer standard Electricorp practice. The current practice is to bolt panels to a Unistrut suppod system as in Figure 2. Some older existing panels on wooden plinths at other Electricorp substations have been strengthened by tying 


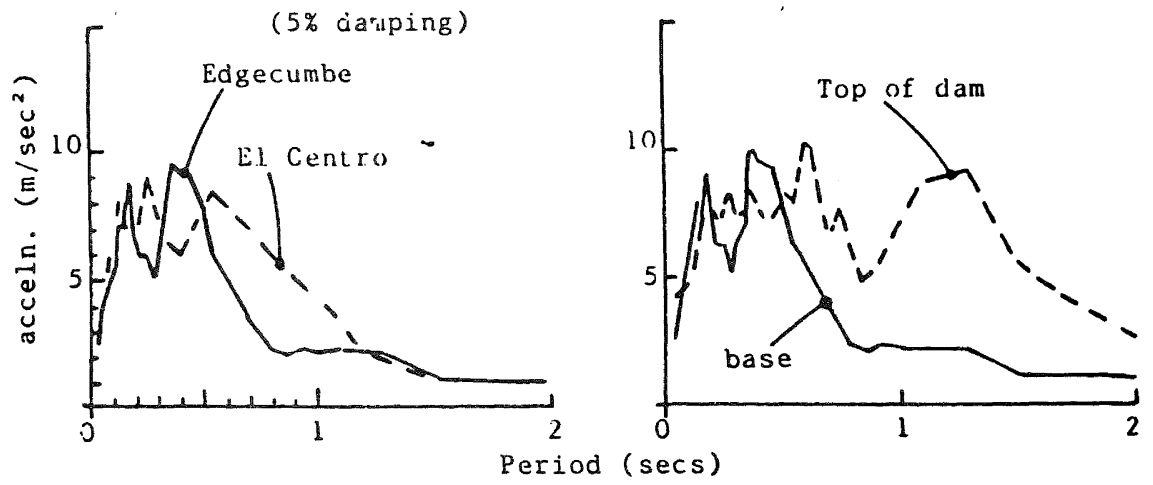

FIGURE 1 RESPONSE SPECTRA AT THE MATAHINA DAM FOR THE EDGECUMBE EARTHQUAKE

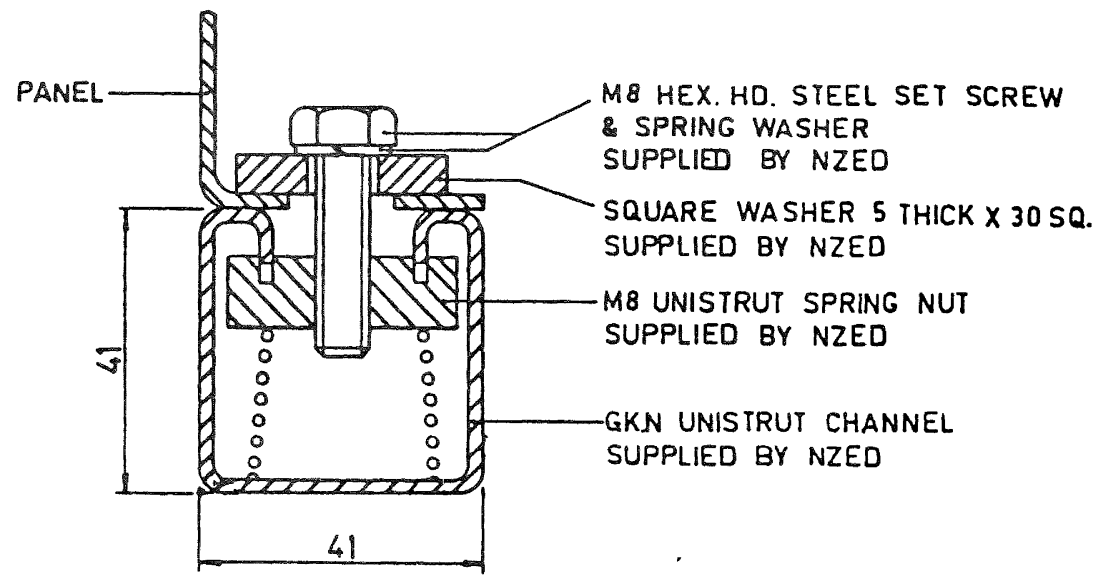

SECTION A.A

Showing bolling down arrangement of panel to Unistrut channel.

FIGURE 2 UNISTRUT SUPPORT SYSTEM FOR PANELS

together at the top and bracing securely to a structural wall.

At Kawerau three control panels out of 35 fell over. The panels are of modern construction $2100 \mathrm{~mm}$ high $\mathrm{x} 600 \mathrm{~mm}$ deep $\mathrm{x}$ $600-800 \mathrm{~mm}$ wide and are secured to the floor via a Unistrut support system. The panels which fell over were installed with $10 \mathrm{~mm}$ countersunk screws without washers instead of the hexagonal bolts and large flat washers specified in the original design. The countersunk heads pulled easily through the cabinet base allowing the panels to topple.

Fortunately at both Kawerau and Edgecumbe the damage to the panels and instruments was fairly minimal and there was sufficient slack in the control cables to accommodate the rotations at the panel bases.

\section{Water Tanks}

The two water tanks at Edgecumbe were about three-quarters full at the time of the earthquake. The sloshing action of the water buckled the iron roof of the tanks but the tanks and roof support structures, were undamaged.

\section{Spares}

In the 80 ton Edgecumbe workshop three out of six unsecured spare $110 \mathrm{kV}$ CTs still in their shipping crates fell over (Figure 3 ). Crates of tools, nuts, bolts and other miscellaneous items were also spread around the workshop floor by the earthquake. The importance of securing spares adequately and good housekeeping practice in general is self evident. 


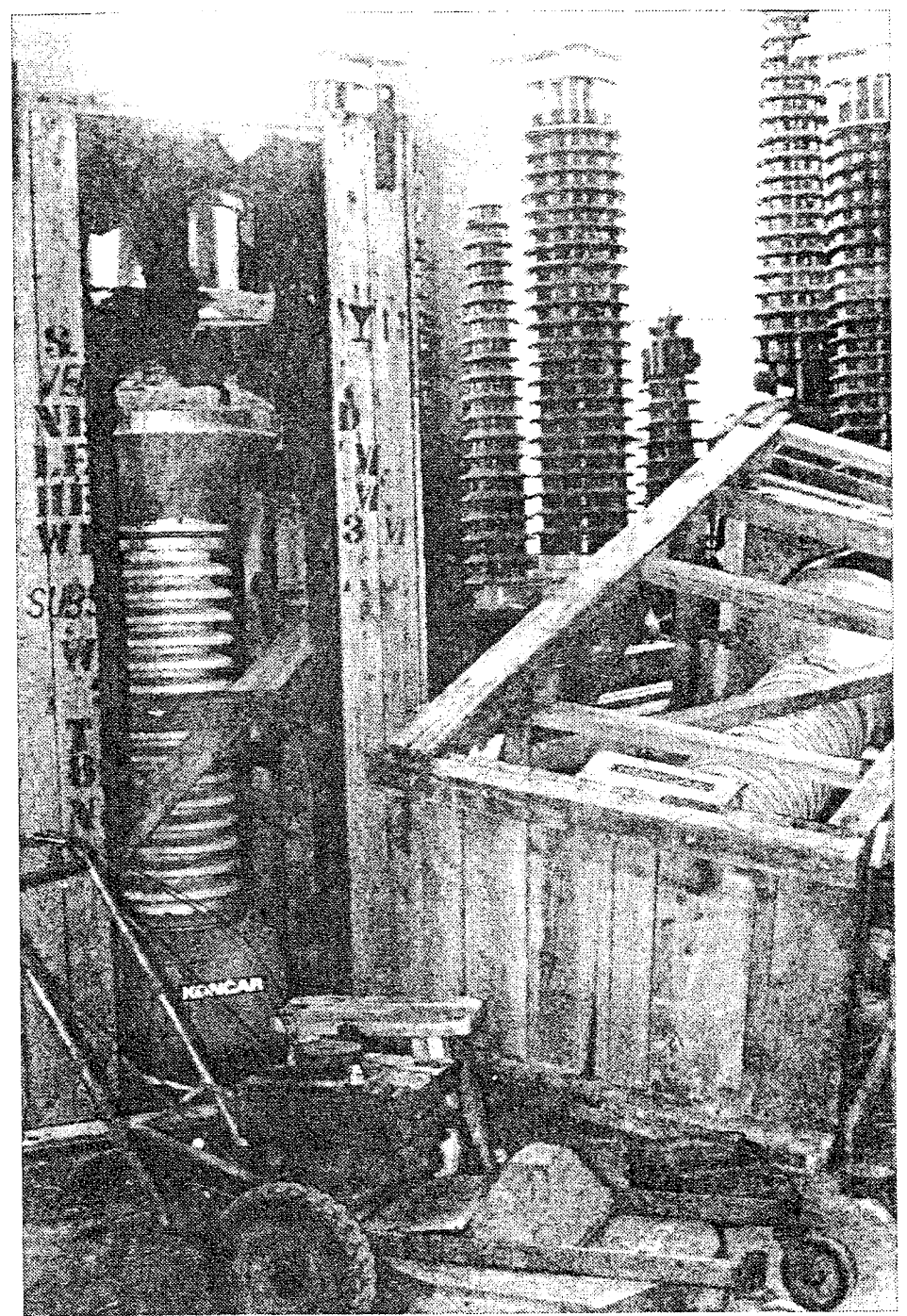

FIGURE 3 SPARE CTS TOPPLED OVER IN THEIR CRATES

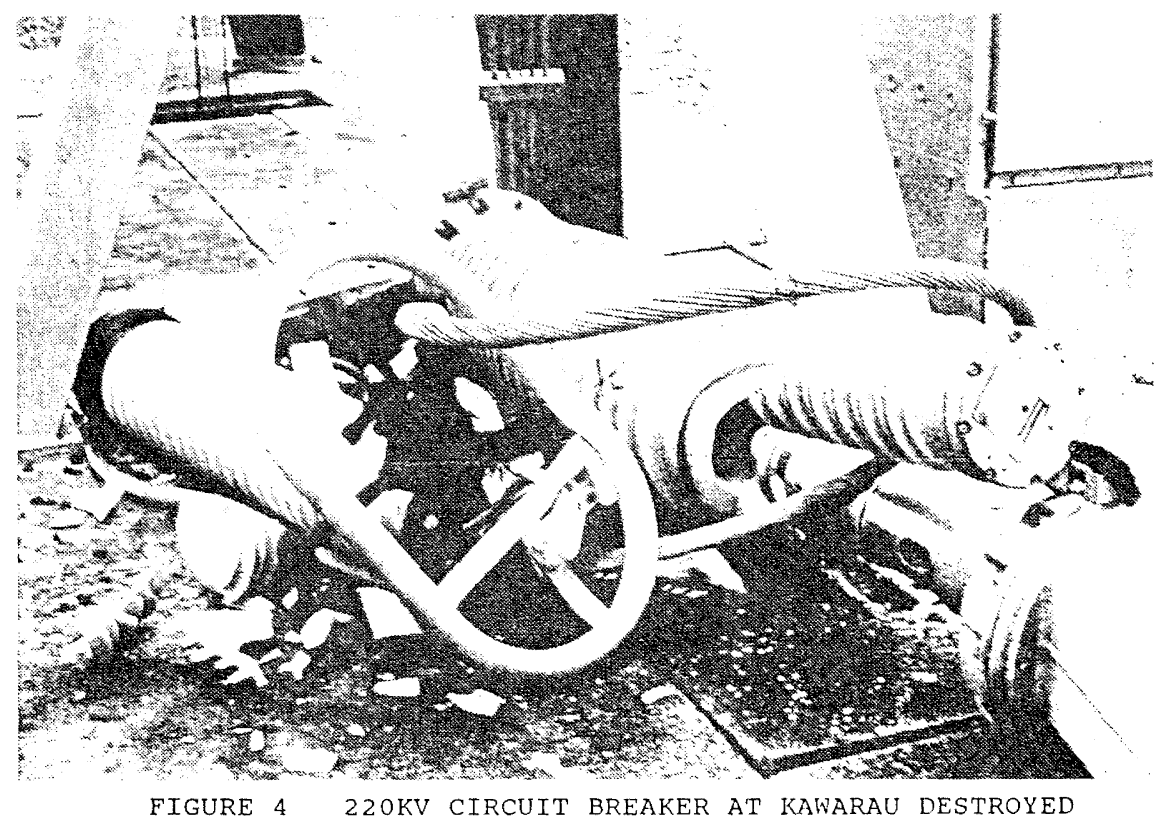


At Kawerau the storeroom within the central building was less affected apart from three gas cylinders which broke the chain securing them to the wall.

\section{Current Transformers}

Seven out of 12 Rade Koncar type APU245 current transformers in the Kawerau $220 \mathrm{kV}$ switchyurd leaked oil after the erartquake. The cause of the leakage was stretching of the clamping bolts at the base of the porcelain. When the CTs were stripped for inspection the support system for the internal windings was also found to be damaged. Clearly the strength of the end fixing arrangement of the porcelain and the strength of the internal Windings support system need to be considered us well as the canlilever strength of the porcelain in the overall assessment of the earthquake resistance of CTs.

At Edgecumbe three $110 \mathrm{kV}$ Brown Boveri CTs cracked at the base of the porcelain and allowed oil to escape. A contributing factor to the failures may have been grinding of the porcelain and stress concentration at the base clamping arrangement, as in the CT failures at Tokaanu substation in March 1984 [3].

A Balteau $220 \mathrm{kV}$ CT at Edgecumbe was also damaged when the adjacent circuit breaker CB482 failed and pulled on the flexible connenection to the CT.

\section{CVTs}

Only one CVT failed and that was a relatively old design ASEA type CT $08 \quad 1 / 22$ at Edgecumbe. The failure occurred at the base of the capacitor support which is a brittle cast iron component. This weakness in the design could easily be corrected by replacing the bottom two castings with fabricated I-beam sections.

\section{Circut Breakers}

In the Kawerau $220 \mathrm{kV}$ switchyard the

blue phase of CB622, a Merlin Gerin $220 \mathrm{kV}$ FA2 CB was totally destroyed (Figure 4). Failure occured at the base of the top support insulator. The falling interupter head then broke the support insulator of the adjacent isolator 624 .

The Merlin Gerin CBs were installed in 1979 and the design met Electricorp current earthquake design specifications. It is likely that the "tight looking" flexible connection to the isolautor caused extra shock loading on the circuit breaker [4].

In the Edgecumbe $220 \mathrm{kV}$ switchyard all six porcelain support columns of the oerlikon $220 \mathrm{kV}$ type FS9C1 CB broke. The classic cantilever bending failure occurred at the base of a weak porcelain column supporting a heavy interrupter head. The oerlikon breaker is on the list of Electricorp circuit breaker types to be strengthened.

In the Kawerau $110 \mathrm{kV}$ switchyard the red phase upper bushing of CB122, on ASEA $110 \mathrm{kV}$ circuit breaker was pulled off its supporting insulator completely, shearing the four mounting bolts. The cause of this failure was probably insufficient flexibility in the electrical connections.

\section{Line Traps}

All line trap support insulators survived. However, at the north end of the Kawerau $220 \mathrm{kV}$ switchyard the insulator terminals on top of the red and blue phase units were broken. The failure was due to relative movement between the line trap and the solid tubular conductor. This damage would not have occurred if a properly designed flexible connection had been installed.

\section{Transformer Holding Down}

There were two basic modes of failure of transformer holding down arrangements at both Kawerau and Edgecumbe:

1) Failure of the transformer undercarriage to rail fastenings.

2) Failure of transformer tank to undercarriage fastenings.

An example of the first mode of failure is shown in figure 5 where all the Metropolitan-Vickers llokv spare transformers at Edgecumbe sheared the $16 \mathrm{~mm}$ bolts securing the holding down brackets to the undercarriage and the rail. As a result the transformers came completely off the rails.

The original holding down brackets are several times taller than the horizontal spacing of the $16 \mathrm{~mm}$ bolts. Therefore horizontal earthquake load in the direction of the rails subjected the $16 \mathrm{~mm}$ bolts to very high shear forces. The brackets were also only originally designed for $0.25 \mathrm{~g}$.

Another example of the first mode failure is the 897 tonne $210 \mathrm{kV}$ BTH bank at Edgecumbe where failure of the $20 \mathrm{~mm}$ bolts securing the holding down brackets to the rails allowed the yellow and red phase units to roll along the rails and ram their respective radiator support structures. consequently the oil pipes between the radiator and transformer were destroyed. The holding down brackets were again only designed for $0.25 \mathrm{~g}$.

A third example of the first mode of failure is the Kawerau 110kV ASEA T1 and T3 banks where the holding down arrangement to the rails was overstressed. The weakest part of the design is the $20 \mathrm{~mm} \times 150 \mathrm{~mm}$ long bolt throufgh the rail. The bolt was subjected to high bending stresses under the actio of combined horizontal and vertical load and the final fracture was tensile. Consequential failure of low voltage bushings with tap changer mechanisms occurred when the transformers moved on their rails.

An example of the second mode of failure is the Kaweruu T2A and T2B Feranti $110 \mathrm{kV}$ banks where the M16 bolts securing the transformers to their undercarriages failed in shear as in Figure 6 .

The Kawerau T5 AEl llokv transformer to undercarriage fixings were also badly designed and the holding down bolts failed in bending. 


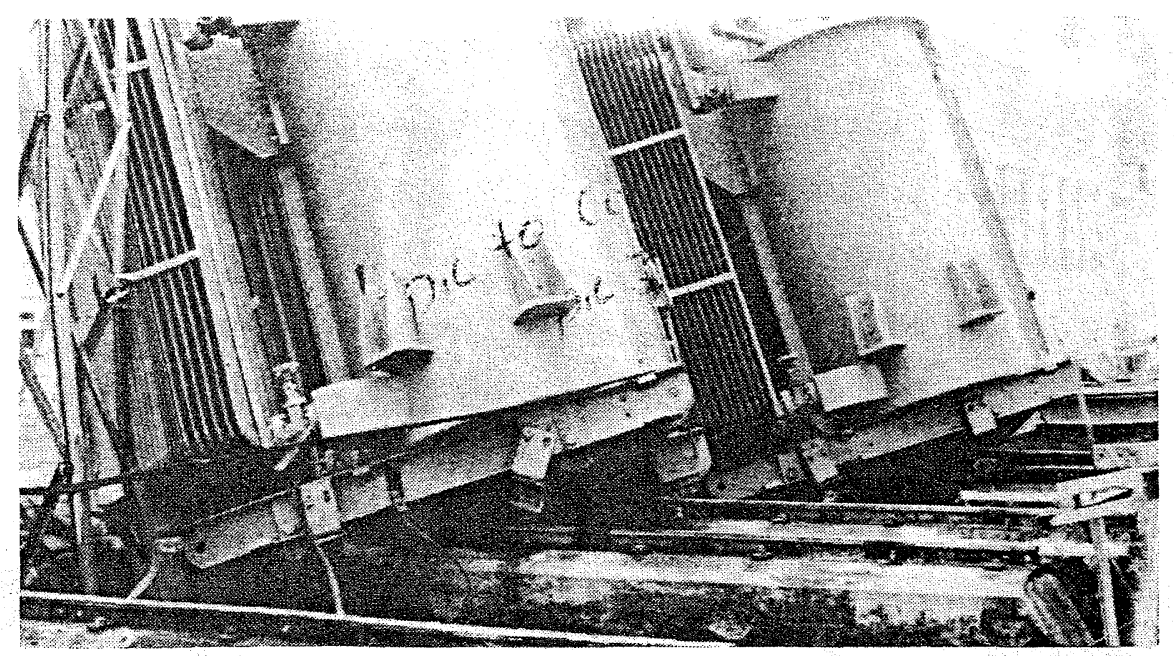

FIGURE 5 110KV TRANSFORMERS AT EDGECUMBE OFF THEIR RAILS

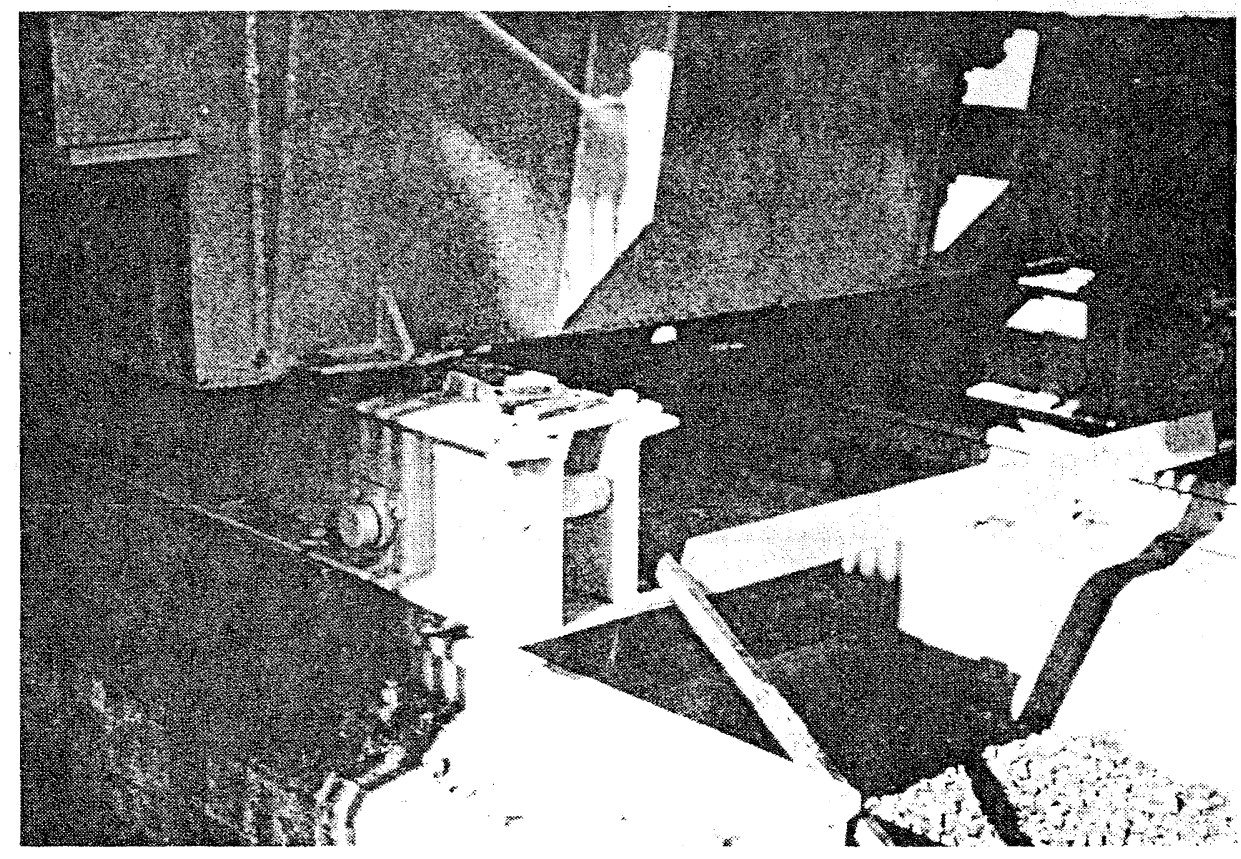

FIGURE 6 11OKV TRANSFORMER AT KAWARAU SHEARED UNDERCARRIAGE/TRANSFORMER BOLTS

At Edgecumbe the M16 bolts securing the spare Ferranti $110 \mathrm{kV}$ transformer to the undercarriage sheared and came to rest against the adjacent Metropolitan-Vickers transformer.

Some transformers suffered both modes of failure. For example, all Savigliano $210 \mathrm{kV}$ T8 transformers at Edgecumbe including the spare came off the rails when the holding down arrangements failed completely. Most of the 20mm studs securing the holding down brackets to the wheels failed in shear as in Figure 7 . The studs were subjected to extremely high shear loads because of the lever action of the relatively long brackets on the narrowly spaced studs as in Figure 8. Even if the transformer wheels had been adequately fastenend to the rails the transformers would not have survived because of the weak attachment of the undercarriage to the transformer tank. Several of the wheels were ripped of either when the transformers left the rails or when they hit the concrete. The holding down arrgements for the Savigliano transformers were desisned to $0.25 \mathrm{~g}$. When the transformers are reinstalled they will be bolted directly to the foundation pad. 

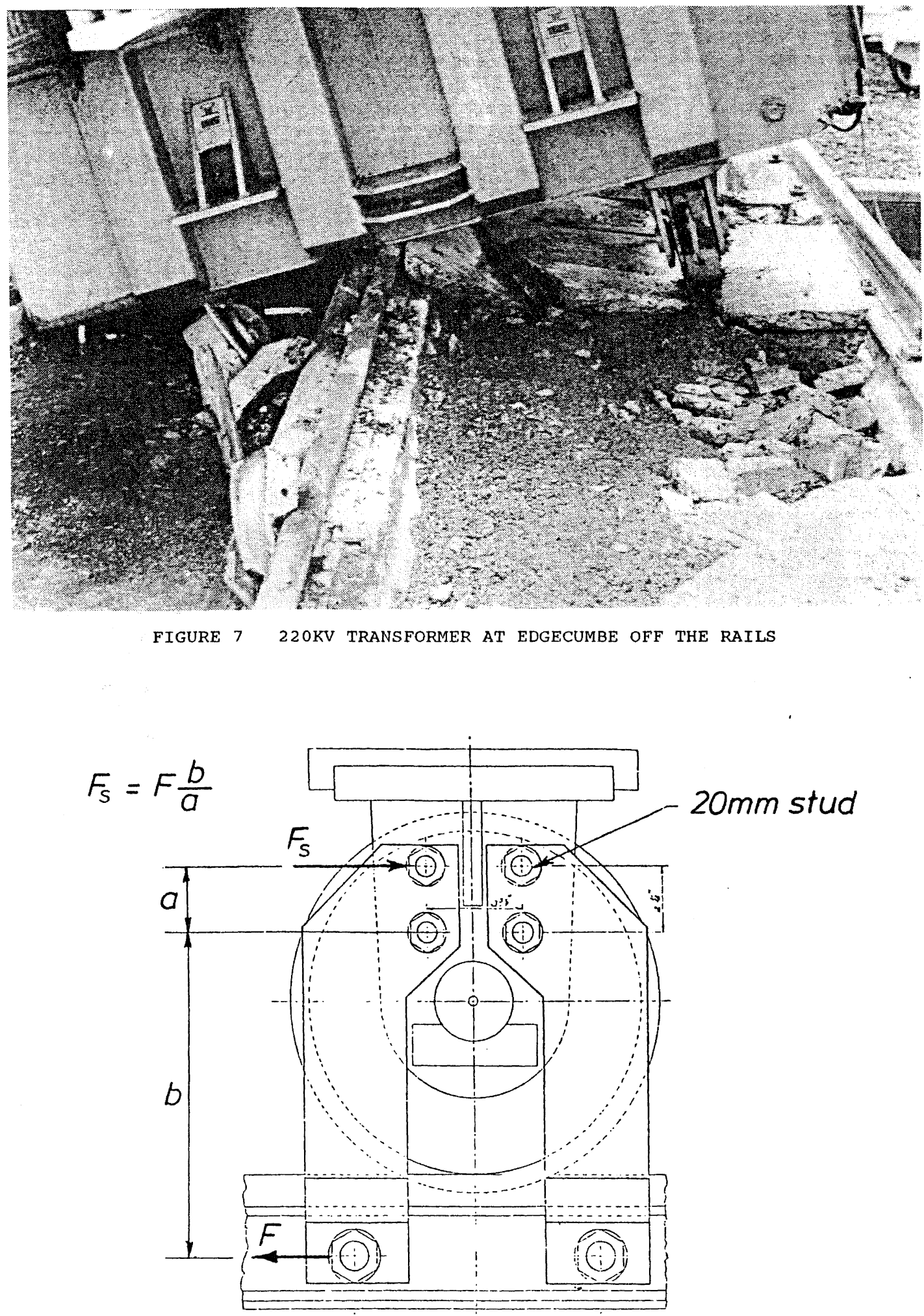

FIGURE 8 EDGECUMBE T8 TRANSFORMERS - SHEAR FORCE ON $200 M M$ STUDS 
Transformer O1l Pipes and Bucholz Relays

on the $\mathrm{T} 6$ and $\mathrm{T} 7 \mathrm{110 \textrm {kV }}$ Tyree transformer coolers at Kawarau some failures of the cross bracing occurred and the resulting excessive movement lead to failure of the pipework at the conservator tank valve.

The Bucholz relays on $\mathrm{T} 12$ and $\mathrm{T} 13220 / 110 \mathrm{kV}$ interconnecting transformers at Kawarau failed and allowed oil to escape. This failure was probably either caused by excessive response of the pipe or by relative movement between the oil conservator and the transformer. The south block wall which forms the enclosure to contain the oil leaked from the transformer fell over. The wall was built with low strength mortar to allow easy removal when the transformers are shifted.

\section{$220 \mathrm{kV}$ Buswork}

The $220 \mathrm{kV}$ buswork at Kawerau was extensively damaged as in Figure 9. Numerous concrete posts which support the insulators and buswork cracked at the base [5] Several long cross-over conductors pulled out of the interconnecting clamps and fell to the ground. One insulator on top of a tall concrete post was compleIely destroyed.

In general the damage to the $220 \mathrm{kV}$ buswork was easily repaired. The concrete posts were originally designed to yield at the base without failing completely.

\section{CONCLUSIONS FROM THE DAMAGE}

\section{Transformer Holding Down}

The transformer damage at Edgecumbe and Kawerau was to units that were not designed to current Electricorp earthquake standards for transformers first introduced in 1969.
For example at Edgecumbe the Savigliano earthquake clamps were designed in 1967 and the clamps for the BTH were designed in 1953. The Ferranti clamps dated back to 1957 and the Westinghouse clamps are even earlier. On the other hand, the osaka holding down design was installed in 1977 and survived well.

At Kawerau the T1 and T3 ASEA clamps were designed in 1955 and the clamps for the T2A Ferranti were designed in 1961. The fact that none of the in-service units came completely off the rails may have been because the predominant direction of ground shaking was parallel to the rails.

The shear failure of the fixings for the T5 AEI and T2A/T2B Ferranti transformers to their undercarriages demonstrates that an earthquake will expose the weakest part of the overall, installation. The manufacturer's method of fixing the transformer tank to the undercarriage should always be checked when holding down arrangements are designed.

If the transformer fastenings had been upgraded to current Electricorp standards for earthquake design most of the damage would have been avoided.

\section{Control Panel Holding Down.}

The failure of the control panels was due to bad working practice. The Unistrut system currently used by Electricorp for holding down panels is satisfactory when correctly installed.

All control panels coach screwed to wooden plinths should be tied back to a structural wall.

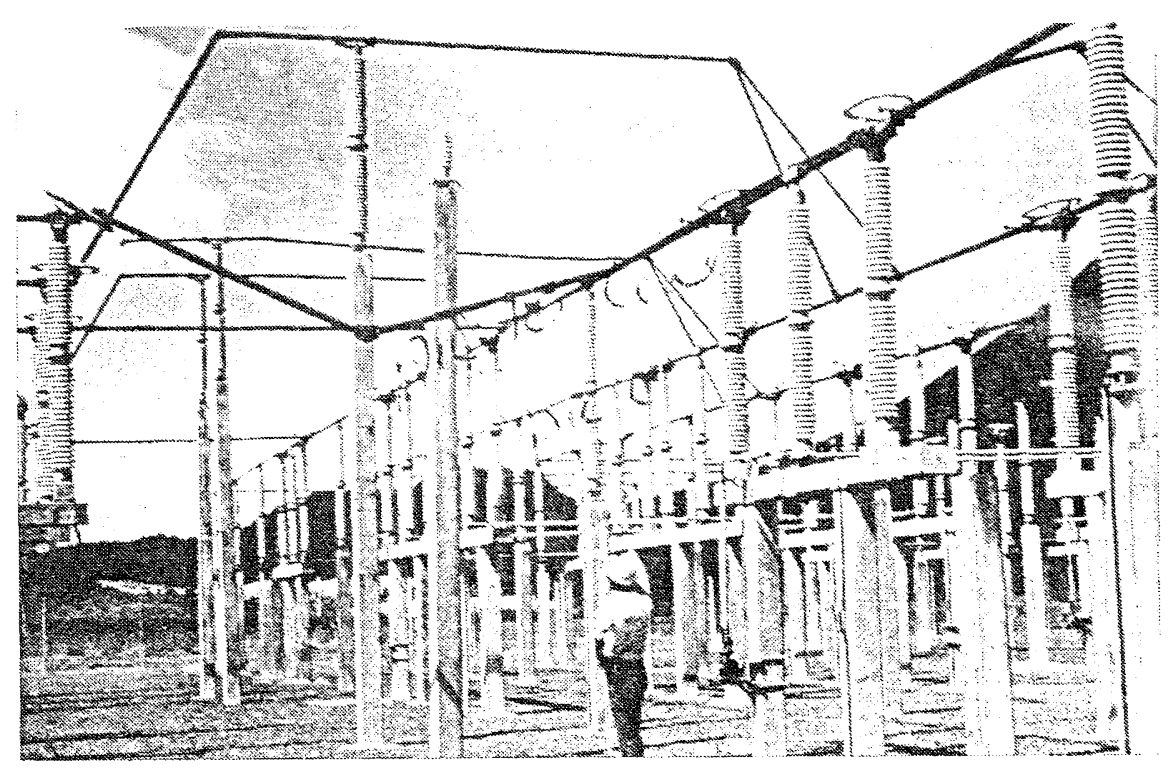

FIGURE $9220 \mathrm{KV}$ BUSBAR DAMAGE AT KAWARAU 


\section{Current Transformers}

In the assessment of overall strength of curent transformers the strength of the end fixing arrangement should be considered. Futhermore the strength of the fixings for the internal windings should be checked.

\section{Flexible Connections}

Flexible connections that were installed with insufficient free length is the likely cause of failure of the Merlin Gerin $220 \mathrm{kV}$ FA2 $C B$ at Edgecumbe and the ASEA $110 \mathrm{kV} \mathrm{CB}$ at Kawerau. Connections should be installed with a generous amount of slack even if it detracts from the overall tidy appearunce of the installation.

\section{spares}

Spares likely to topple in an earthquake should be secured to the floor or tied back to a wall.

\section{Equipment that Survived}

The most notable survivor of the earthquake was the Delle $220 \mathrm{kV}$ CBs at Edgecumbe. As originally installed the breakers would not survive the Electricorp design earthquake. The breakers were retrofitted with Belville washer dampers to improve the earthquake resistance and this simple modification probably saved them from damage in the Edgecumbe earthquake.

\section{RECOMMENDATIONS FOR SUPPLY AUTHORITIES}

The Bay of Plenty earthquake was a sharp reminder that electrical equipment is very. vulnerable to damage if it is not designed to withstand earthquake induced forces or is not adequately held down. In November 1981 a set of notes was issued to all Supply Authority staff on the application of ESR61. This set of notes was prepared by NZE staff for a working group comprising Supply Authority and NZE engineers. The notes provide guidance on achieving an adequate degree of earthquake resistance for power houses and substations as required by the 1980 amendment to ESR 61 and its associated Gazette notice of 23 october 1980.

Supply Authority staff involved in the design of new installations or the upgrading of existing equipment should use the guidelines given in the notes and consult if necessary with engineers expenenced in the earthquake resistant design of electrical equipment.

\section{ACKNOWLEDGEMENTS}

The author wishes to thank the Management of Electricorp for permission to publish this paper. The assistance of Mr Tan Pham in gathering material for this paper is gratefully acknowledged.

\section{REFERENCES}

1. Pender,M.J. et al, "The Edgecumbe Earthquake - a Brief Report", April 1987.

2. Rutledge, A.L. and T. Pham, "The Bay of Plenty Earthquake - A Preliminary Assessment of Earthquake Damage at Kawerau and Edgecumbe", Internal Electricorp report, March 1987.

3. Rutledge, A.L. and T. Pham, "Investigation of Equipment Failures in the Tokaanu outdoor Switchyard due to the Earthquake of 5 March 1984" Electricorp Research Section Report No. R55/85, August 1985.

4. Pham,T., "Earthquake Failure of Merlin Gerin $220 \mathrm{kV}$ IA2 Circuit Breaker at Kawerau Substation", Electricorp Research Section Technical Note T87/41

5. Coad,J.N.O., "220kV Buswork support post Performance during the Bay of Plenty Earthquake", Electricorp Research Section Technical Note T87/39. 